\title{
Dental Arch Size, Biting Force, Bizygomatic Width and Face Height in Three Colombian Ethnic Groups
}

\author{
Tamaño del Arco Dental, Fuerza de Mordida, Anchura Bizigomatica \\ y Altura Facial en Tres Grupos Étnicos Colombianos
}

Bedoya, A.*; Osorio, J. C.** \& Tamayo, J. A.***

BEDOYA, A.; OSORIO, J. C. \& TAMAYO, J.A. Dental arch size, biting force, bizygomatic width and face height in three Colombian ethnic groups. Int. J. Morphol., 33(1):55-61, 2015.

SUMMARY: The objective of this study was to describe transversal dimensions of the dental arches, bite force and facial index in three ethnic groups representative of Colombia. The sample size included 197 adolescents, 12 to 14 year old, 33\% mestizo, 35\% of African ancestry and 32\% Amazon Indian; 50.3\% male and 49.7\% female. The comparative analysis to determine differences between ethnic groups was made by the Kruskal Wallis test and then the Principal Component Analysis was used to establish the pattern of measurements identifying ethnic characteristics. All measurements showed statistically significant differences among ethnic groups except facial height $(\mathrm{p}=0.157)$. It was evidenced that Amazon indian have a higher bite force $(\mathrm{p}<0.05)$ than the other twoethnic groups. Regarding dental arch transversal dimensions, Amazon Indian have a higher arch transversal width with a length average of $44.1 \mathrm{~mm}$. This length was greater than mestizo adolescents $(M=36.7 \mathrm{~mm})$ and Afroamerican $(\mathrm{M}=38.3 \mathrm{~mm})$. In conclusion, the amazon Ticuna Indian ethnia has a significantly higher bite force, higher dental arch transversal width and higher bizygomatic width than the other two ethnic groups considered.

KEY WORDS: Facial biotype; Bite force; Dental arch; American ethnia.

\section{INTRODUCTION}

Human biotype is a model to describe phenotypic variability among individuals and within and among populations. There are three basic facial biotypes: brachyfacial, mesofacial, and dolichofacial. Brachyfacial describes a horizontal growth pattern, dolichofacial a vertical growth pattern (Ricketts, 1960), and mesofacial a well-balanced face with harmonious musculature and a pleasant soft tissue profile (Clark, 2002).

In 1957 Martin \& Saller defined facial biotype by an index obtained with the facial height (Distance Nasion "N" Gnation "Gn") multiplied by 100 and divided by facial width (zygomatic distance from right "Zd" to left "Zi") (Rakosi \& Irmtrud, 1992). Many studies have used this index to classify the facial biotype but the ethnic differences are not considered. Recent evidence shows that variability in biotyping is relevant for ethnic identification (Lu et al., 2005).

The skeletal craniofacial morphology and craniocervical relationships have direct influence on masticatory and respiratory functions (Kiliaridis et al., 1985). Some reports show that biting force in adults with rectangular craniofacial morphology and skeletal deep bite is higher than in adults with long face morphology and open bite. There are also studies evaluating the biting strength in different population groups and its importance to the occlusal function and postorthodontic treatment demands (Shinogaya et al., 2001). Other studies report the relationship between maximum masticatory force and craniofacial morphology (Sondang et al., 2003). The results showed a larger bite force implies a greater posterior facial height, smaller gonial angle, larger maxilla and straighter posterior length of the cranial base. This study suggests that among Indonesians, maximum bite force could be explained by craniofacial morphology as found in Caucasians.

Transversal dental arch dimensions have been used as well to classify the dental arch forms evaluating their difference per sex, tooth size and age (Nakatsuka et al., 2004). Facial length has been negatively correlated to dental arch width (Forster et al., 2008).

* Ortodontista D. Sc.D. Posgrado de ortodoncia y ortopedia maxilar. Institución Universitaria Colegios de Colombia (UNICOC), Cali, Colombia.

** Biólogo. MSc. Posgrado de ortodoncia y ortopedia maxilar. Institución Universitaria Colegios de Colombia (UNICOC), Cali, Colombia.

**** Estadístico. Posgrado de ortodoncia y ortopedia maxilar. Institución Universitaria Colegios de Colombia (UNICOC), Cali, Colombia. 
A recent analysis (Bedoya et al., 2012), facial biotype morphology was classified considering only the measures described by Rakosi \& Irmtrud. In addition, the facial biotype is modeled through the bite force variables, bizygomatic distance $(\mathrm{Zr}-\mathrm{Zl})$, face height $(\mathrm{N}-\mathrm{Ng})$ and transverse distances of the arcs. The statistical method of fuzzy clusters was used to determine the number of groups or biotypes for each type of ascendancy. It was concluded that mixed populations and African descent have similarities, therefore they were grouped together and the c-means algorithm generated four biotypes characteristic, while the indigenous population Ticuna (Amazon) only generated three biotypes.

Using a Structural equation modeling was validated the causal relations of three different types of mediating variables: masticatory force, transverse measures, dental arches, bizygomatic width, and morphological face height. It model showed that the variable that best correlated with facial biotype was masticatory force (0.82), followed by dental arches relation (0.73), with a moderate correlation. The previous study established a number of categories related to the population ancestry. Further, when the ethnic factor isn't considered the classification deficiencies on FMI were evidence (Bedoya et al., 2013).

The purpose of this study was to characterize the biting force, dental arch width and $\mathrm{N}-\mathrm{Gn}$ and $\mathrm{Zr}-\mathrm{Zl}$ dimensions. Further, the type of relationship between measures in three ethnic groups of Colombia was determined.

\section{MATERIAL AND METHOD}

Participants. The study included 197 adolescents, 12 to 14 years old, selected from three ethnic Colombian communities; $33 \%$ of them are mestizo from the city of Cali (Valle del Cauca), 35\% Afroamerican from Puerto Tejada (Cauca) and 32\% indian from a Ticuna community living in Leticia (Amazonas). Sex distribution was homogeneous: $50.3 \%$ male and $49.7 \%$ female. The average body weight of the adolescents was $43.9 \mathrm{~kg}$ (SD: $6.31 \mathrm{~kg}$ ) and body height $1.53 \mathrm{~m}$ (SD: $0.07 \mathrm{~m}$ ), giving a calculated average Body mass index of 18.68 .

Inclusion and exclusion criteria. The ethnic assignment was based upon data from three generations according to information provided by direct communication with the family members. We only selected children with bilateral neutral-occlusion canine Class I, bilateral Class I molar relationship and completely healthy after medical, orthodontic and pediatric dental evaluation; verifying the presence of all teeth without alteration of form, structure or number, as well as normal oral tissues, besides none had craniofacial joint or muscle anomalies. Individuals with craniofacial disorders or different age range were excluded. Informed consent from the community leader and parents or care givers was previously obtained.

Facial morphology. Two facial measurements were taken to the participants: Distance Nasion $(\mathrm{N})$ - Gnation $(\mathrm{Gn})$ and zygomatic distance from right ( $\mathrm{Zr}$ ) to left (Zl). For this purpose, a Bull-tools digital caliper was used (up to $0.01 \mathrm{~mm}$ accuracy). These are the measurements used in calculating facial morphological index (FMI) which is obtained from the relationship between morphological face height (from $\mathrm{N}$ to $\mathrm{Gn}$ ) and bizygomatic width ( $\mathrm{Zr}-\mathrm{Zl}$ ), as described by Rakosi \& Irmtrud. These measures were taken directly from the patient's face and was held only once by an observer.

Biting force. It was measured with a previously calibrated gnatodinamometer (GM10 Nagano Keiky, Japon) with a measurement range of $0-1000 \mathrm{~N}$ with an accuracy of $\pm 1 \mathrm{~N}$ (Varga et al., 2011), by two investigators trained and calibrated in 20 patients of UNICOC Clinics in Cali. The biting force was registered in Newton $(\mathrm{N})$ in three dental arch zones: incisive, premolar and molar zones. Only the maximum of three values obtained with 5 minutes interval was registered for each zone.

Dental arch transversal dimensions. Alginate impressions of maxillary and mandibular arches were taken to prepare models in type III dental plaster. With a digital calibrator (Buffalo, up to $0.01 \mathrm{~mm}$ accuracy) the distance from the right first premolar vestibular cuspid tip to the left first premolar vestibular cuspid tip was measured in the maxillary dental arch. Similarly, the distance from right to left permanent first molar mesiobuccal cuspid was obtained. In the mandibular dental arch the same distance for first premolar and first molar width was measured.

The above was followed by standardization of the measurements of facial morphology, masticatory force and transverse dimensions, with two evaluators, in a pilot sample of 20 patients treated at the Institución Universitaria Colegios de Colombia (UNICOC) Orthodontic Clinic (Cali), obtaining an intraclass correlation index greater than 0.85 for all the measurements under study; this means that the obtained value shows good inter-observer agreement. Two evaluators were needed to complete the measurements in less time.

Statistical Analysis . For statistical analysis the program R was used, a language and environment for statistical 
computing (Development Core Team 2012) and the "stats" and "ade4" version 1.4-1 libraries. Analysis was performed by nonparametric Kruskal-Wallis test to determine differences in univariate measures taken to each ethnic group, since the normality test of Shapiro-Wilks was sufficient evidence to reject the hypothesis of normality of the data $(p<0.05)$. Then we used the Principal Component Analysis (PCA, hereinafter) to establish the pattern of the measures studied between the three ethnic groups and identify the characteristics of each group within the multivariate space. The level of significance for all tests was 0.05 .

\section{RESULTS}

Table I presents the average and standard deviation for each variable and ethnic group. Previously determined by the nonparametric Mann-Whitney test that there are no statistically significant differences in bite force between men and women in both age groups and the three ethnic groups $(\mathrm{p}<0.05)$, as in the measures of the dental arch size and facial width and height $(p<0.05)$ (data not shown). The differences between groups were statistically significant for all variables except Facial height $(\mathrm{p}=0.157)$. The Ticuna indian group presented a significantly higher bite force in all the dental zones measured ( $\mathrm{p}<0.001$ ), as compared to the other ethnic groups.

The transversal anterior maxillary width was respectively $\mathrm{M}=44.1 \mathrm{~mm}$ for the Ticuna group; $\mathrm{M}=36.7 \mathrm{~mm}$ for mestizo group and $\mathrm{M}=38.3 \mathrm{~mm}$ for the afro group. This difference among groups is statistically significant. For posterior maxillary transversal width the respective average results are: $\mathrm{M}=54.2 \mathrm{~mm}$ for Ticuna members; $\mathrm{M}=46.9 \mathrm{~mm}$ for mestizo and $\mathrm{M}=47.4 \mathrm{~mm}$ for afro.
In the mandibular dental arch the only significant difference was obtained in the mestizo group whose dental arch anterior and posterior width was lower than afro or Ticuna groups. Bizygomatic distance is higher in the Ticuna group $(M=132.4 \mathrm{~mm})$ than in the other two groups $(\mathrm{p}<0.001)$.

The main features of the measures studied in ethnic groups are displayed graphically to make the ACP. The first three components together explain $74.4 \%$ of the total variance. The first component explains $47.9 \%$ of the variance; the second component explains $17.1 \%$ of the variance, while the third component explains $9.4 \%$ of the variability. In the negative region of the first component, all bite force data provide the highest factorial charge and the effect is most representative. The dental arch transversal width is also highly representative (Fig. 1A). In the same region the bizygomatic width $(\mathrm{Zr}-\mathrm{Zl})$ is quite representative as well. The parameters for bite force and dental arch transversal width are not significantly correlated in this region. In the positive region the second component is represented by the morphologic facial height $(\mathrm{N}-\mathrm{Gg})$, which explains the low correlation with the other variables. Figure 1B, shows that in the studied ethnia there are probably three dimensions expressed by inter and intra-correlated variables, that is, a moderate correlation exists within the group of variables for the same dimension but there is strong correlation between variables defining each dimension. Two dimensions are visualized in the first components represented by bite force and dental arch transversal width. The third dimension is represented by variables related to facial index (N-Gg and $\mathrm{Zr}-\mathrm{Zl})$.

According to a global analysis, the indigenous children data are concentrated in the negative part of the first component, therefore they are distinguished by having the strongest bite force, highest dental arch transversal size

Table I. Mean (M) and standard deviation (SD) results per ethnic group.

\begin{tabular}{lccccccc}
\hline & \multicolumn{2}{c}{$\begin{array}{c}\text { Mestizo } \\
(\mathbf{n = 6 5})\end{array}$} & \multicolumn{2}{c}{$\begin{array}{c}\text { Afro } \\
\text { (n=69) }\end{array}$} & \multicolumn{2}{c}{$\begin{array}{c}\text { Ticuna } \\
(\mathbf{n = 6 3})\end{array}$} \\
\cline { 2 - 6 } & $\mathrm{M}$ & $\mathrm{SD}$ & $\mathrm{M}$ & $\mathrm{SD}$ & $\mathrm{M}$ & $\mathrm{SD}$ & $P$ \\
\hline Bite force. Incisive zone (FI) Newton & 144.7 & 47.8 & 154.5 & 58.1 & 270.5 & 88.6 & $<0.001$ \\
Bite force. Right premolar (FPD) Newton & 266.7 & 118.1 & 395.8 & 120.8 & 530.1 & 169.7 & $<0.001$ \\
Bite force. Molar right (FMD) Newton & 492.2 & 134.7 & 522.5 & 118.2 & 677.4 & 178.3 & $<0.001$ \\
Bite force. Premolar left (FPI) Newton & 370.1 & 130.1 & 371.1 & 97.9 & 482.5 & 167.6 & $<0.001$ \\
Bite force. Molar left (FMI) Newton & 537.8 & 130.2 & 550.3 & 116.1 & 668.7 & 161.4 & $<0.001$ \\
Maxillary anterior transversal width (DTAS) mm & 36.7 & 2.4 & 38.3 & 3.0 & 44.1 & 3.1 & $<0.001$ \\
Maxillary posterior transversal width (DTPS) mm & 46.9 & 2.1 & 47.4 & 3.0 & 54.2 & 3.2 & $<0.001$ \\
Mandibular Anterior transversal width (DTAS) mm & 32.0 & 1.4 & 36.2 & 3.6 & 36.8 & 3.0 & $<0.001$ \\
Mandibular posterior transversal width (DTPS) mm & 42.8 & 2.8 & 45.5 & 3.6 & 48.1 & 3.1 & $<0.001$ \\
Morphologic facial height (N-Gg) mm & 117.0 & 9.9 & 114.1 & 7.3 & 113.1 & 3.3 & 0.162 \\
Bizygomatic distance (Zr-Zl) mm & 113.3 & 6.4 & 108.9 & 8.8 & 132.4 & 4.5 & $<0.001$ \\
\hline
\end{tabular}


and highest bizygomatic width as compared to the other two ethnic groups studied (Fig. 2A). On the other hand, the difference between afro and mestizo groups is featured by the morphologic facial height as the mestizo group tends to be located at the negative area of the second component, although the difference is not significant (Fig. 2B).
A reconstruction based on the parameters measured, will evidence that the individual is of the amazon Ticuna indigenous ethnia if the bite force, the dental arch transversal width and bizygomatic width is highest than the average values either for mestizo or afro.

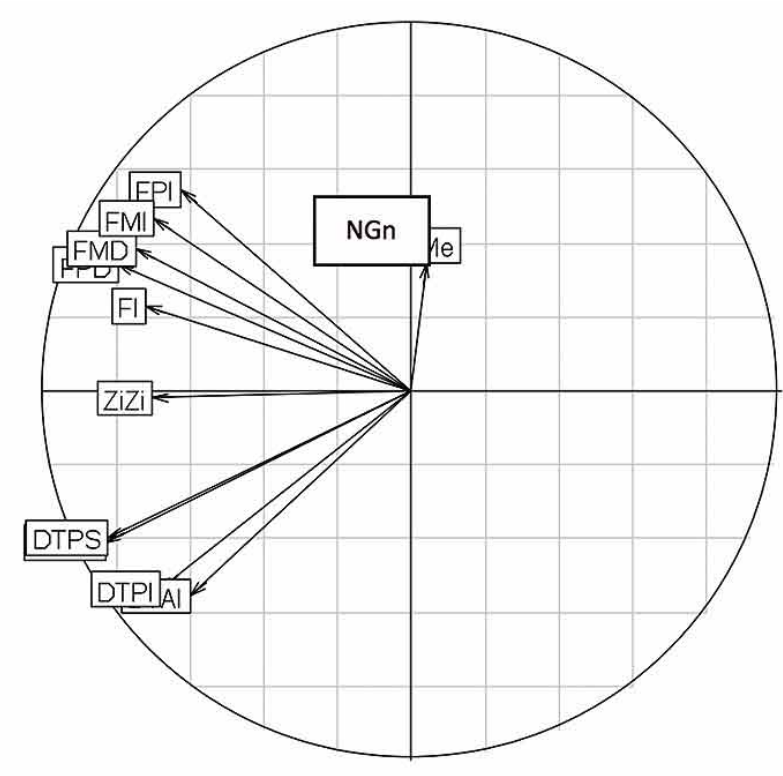

A

Fig. 1. A. Circle of correlations for the main two principal components in the point cluster. B. Circle of correlations for the second and third principal components in the point cluster.

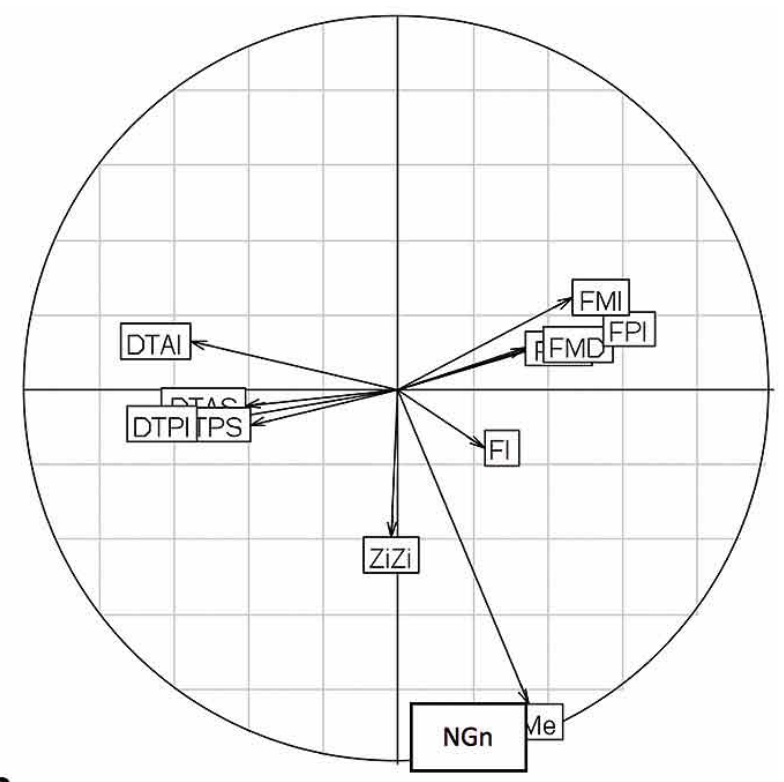

B
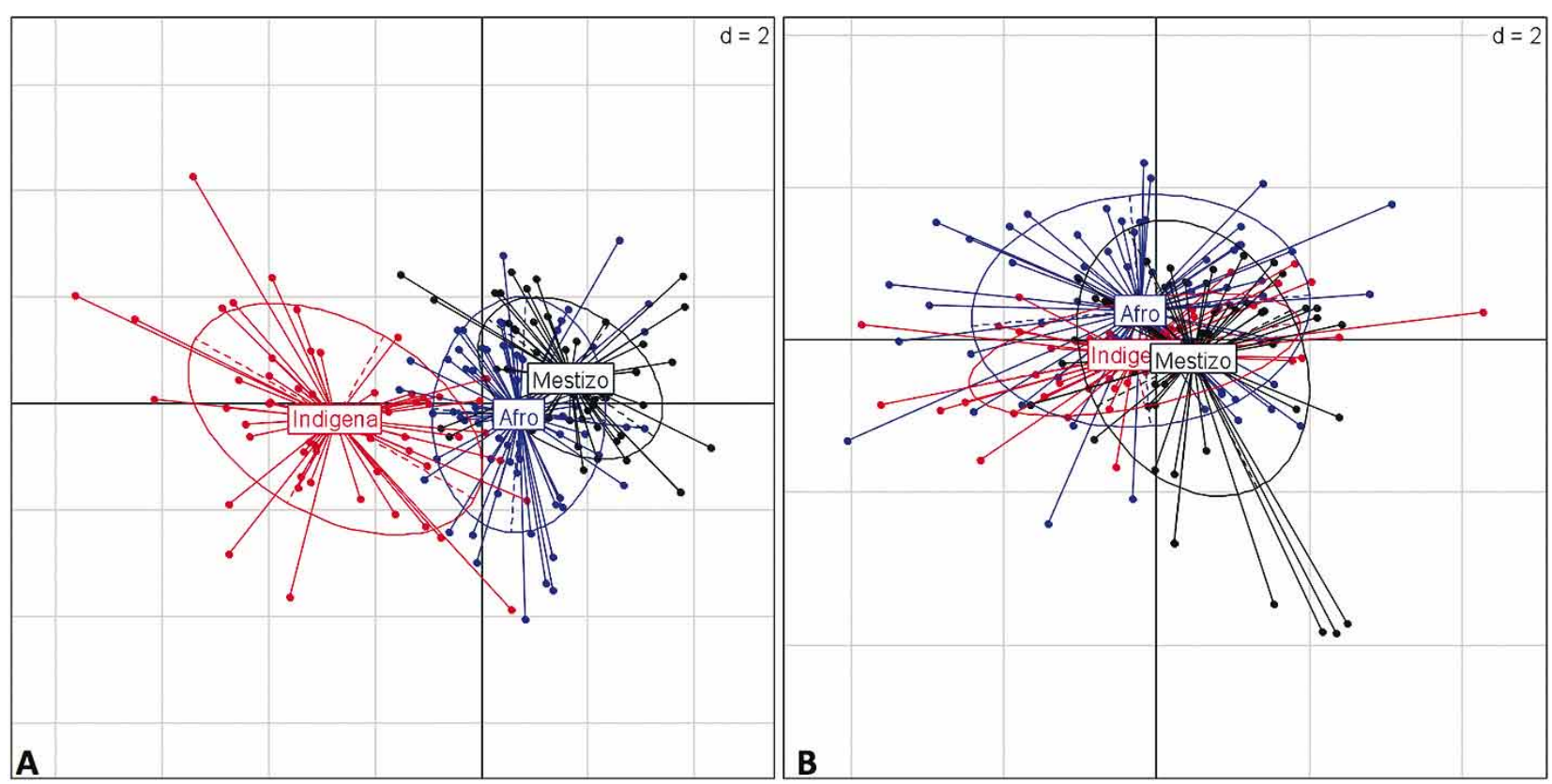

Fig. 2. A. Projection of the ethnic groups in the factorial plane of first and second components. B. Projection of the ethnic groups in the factorial plane of the second and third component. 


\section{DISCUSSION}

Bite force. Accurate measuring of bite force is difficult and compounded by a number of interrelated factors, such as the occlusion, the presence of dental diseases, the architecture of the occlusal surfaces and the intermaxillary space (Abu Alhaija et al., 2010). Furthermore, the variations in bite force measures may be due to factors such as the degree of cooperation of the participating children and other independent variables such as age, sex or physiological development. The magnitudes reported in this study provide evidence showing that there is substantial variation among indigenous ethnic populations and the other groups (afro descendant and mixed).

It has been reported that short-faced individual exhibit greater bite force measures than individuals of intermediate and long face (Abu Alhaija et al.; Bedoya et al., 2005). In this sense, indigenous populations of brachyfacial biotype characterized by wider maxillary and squarer jaws, have craniofacial structure that has encouraged the development of greater bite force, compared with individuals having dolichofacial biotype (own mestizos and African descent) (Bedoya et al., 2012). Additionally, indigenous communities exhibit greater occlusal wear that affects the formation of a larger occlusal contact surface (Gavião et al., 2007; Regalo et al. 2008).

Furthermore, dietary habits are also an important factor in increasing the force of biting. The results presented show that indigenous children who maintain a semi-rural lifestyle and a dry fibrous and hard diet, have a bite force that, as well as being higher than that of the other populations studied, increases significantly with age. Consistent with this, Regalo et al. recorded higher bite force measurements in Brazilian indigenous population than white population, attributing such differences in the dietary habits of each group. Research done in rural populations in Japan and Europe also support that described herein (Kamegai et al., 2005, Sonnesen \& Bakke 2005). Thus, the consumption of smooth consistency food is a factor that may be related to the decrease in bite force; it is proposed that the change in diet over the past centuries has decreased masticatory functional demands, leading to reduce the dimensions of the dental arches, favoring the emergence of malocclusion (crooked teeth, crossbites) (Lindsten et al., 2002; Evensen \& Ogaard, 2007).

Transversal dimensions. The results of the present study clearly indicate that transversal size of the dental arch, anterior or posterior, maxillary or mandibular, is bigger in the amazon Ticuna indigenous ethnia than in afro or mestizo ethnia. For the afro descendent ethnia dental arch transversal size is bigger than that found in mestizo but inferior to the indigenous group.

Dental arch size depends on tooth size, buccolingual tipping, functional response to masticatory loads, habits and genetic factors (Ross-Powell \& Harris, 2000). It is also reported that some ethnic groups, such as Australian Aborigines, whose diet is still fibrous and dry develop more muscle work demanding additional stomatognathic system effort, that in turn determines wider maxillary dental archs (Keski-Nisula et al., 2003), as could be the case in Amazon Indian groups, described as having well developed transversal size, harmonic occlusal relations, low grade of dental crowding and not frequent open and cross bite (Bedoya et al., 2005). For Colombian population dental arch transversal and anteroposteriordimensions were compared in three ethnic groups showed differences in intercanine distance, as well as between premolar and between molar teeth. The same differences were found for lower dental arches. The populations evaluated show distinctive characteristics in dental arch dimensions, thus the mestizo population had narrow arches while the natives had wide arches (Padilla $e t$ al., 2013).

The dental arch dimensions in contemporary populations tend to be reduced, although body height tends to increase, hence it is considered that dental arch size is not necessarily proportional to body size. Better care and nutritional supplements do not have significant influence on dental arch transversal dimensions (Alvaran et al., 2009).

Bizygomatic width and morphological face height. The results of this study indicate that morphologic face height $(\mathrm{N}-\mathrm{Ng})$ is higher in the mestizo population of Cali, Colombia than in the Amazon indigenous group that presents a low value. Contrary to it bizygomatic width $(\mathrm{Zr}-\mathrm{Zl})$ in indigenous population is higher than in Cali mestizo that presents the lowest average for this measurement.

Homo sapiens sapiens face inevitably reflects different ethnic phenotypes as a consequence of microevolution processes, genetic drift and continental migration. For amazon groups belonging to Ticuna, Huitoto and Cocama communities, we described the presence of winging, central and lateral shovel shape incisives, high frequency of groove and fossa forms in the Carabelli cusp, cuspid pattern Y6 or Y7, deflecting wrinkle, protostylid and sixes cuspid (Aragón et al., 2008). These morphologic traits are part of a mongoloid dental complex, specifically 
synodont, which is considered to support the theory of mongoloid origin of South American Indians (Aragón et al.).

Besides the origin of Amazon populations, the influence of muscle strength and external stimuli to mold facial biotype (genetic and environmental factors that reinforce external characteristics) are reflected in the Amazonic population in the high bizygomatic width (Mao $\& \mathrm{Nah}, 2004)$, that in general is responsible to the commonly described wide and short face (euriprosopic). These traits are different in the mestizo group of Cali, as their microevolutive process and population dynamics is rather different, giving a facial biotype longer and shorter (leptoprosopic). The afro population presents intermediate characteristics between the mixed Cali population and the amazon indigenous population.

\section{CONCLUSIONS}

The differences between groups were statistically significant for all variables except Facial height. Amazon Ticuna indian ethnia has a significant higher bite force, higher dental arch transversal width and higher bizygomatic width than the other two ethnic groups considered. Mestizo ethnia presents the lowest dental arch size and bite force, and the highest facial height. Afro descendent ethnia presented intermediate results for bite force, dental arch transversal width and bizygomatic width. For all variables analyzed, a higher correlation existed within groups (dental arch size, biting force, bizygomatic width and face height) while correlations between groups of variables resulted moderate.

BEDOYA, A.; OSORIO, J. C. \& TAMAYO, J. A. Tamaño del arco dental, fuerza de mordida, anchura bizigomatica y altura facial en tres grupos étnicos Colombianos. Int. J. Morphol., 33(1):55-61, 2015.

RESUMEN: El objetivo fue describir las dimensiones transversales de los arcos dentales, la fuerza de mordida y el índice facial en tres grupos étnicos de Colombia. El tamaño de la muestra fue de 197 adolescentes, de 12 a 14 años; 33\% mestizos, 35\% de ascendencia africana y $32 \%$ indio amazónico; 50,3\% hombres y 49,7\% mujeres. El análisis comparativo para determinar las diferencias entre los grupos étnicos se hizo mediante la prueba de Kruskal Wallis y luego el Componente Principal de Análisis se utilizó para establecer el patrón de las mediciones para identificar las características étnicas. Todas las mediciones mostraron diferencias estadísticamente significativas entre los grupos étnicos, excepto la altura facial $(\mathrm{p}=0,157)$. Se evidencia que el indio amazónico tiene una mayor fuerza de mordida $(\mathrm{p}<0,05)$ que los otros dos grupos étnicos. En cuanto a las dimensiones transversales del arco dental, el indio amazónico se caracterizó por tener un mayor ancho, con una longitud media de 44,1 mm. Esta longitud es mayor que en los adolescentes mestizos $(\mathrm{M}=36,7 \mathrm{~mm})$ y afroamericanos $(\mathrm{M}=38,3 \mathrm{~mm})$. En conclusión, la etnia india amazónica Ticuna tiene una fuerza de mordida significativamente mayor, así como mayor ancho del arco dental transversal y ancho bicigomático que los otros dos grupos étnicos considerados.

PALABRAS CLAVE: Biotipo facial; Fuerza de mordida; Arco dental; Etnia americana.

\section{REFERENCES}

Abu Alhaija, E. S.; Al Zo'ubi, I. A.; Al Rousan, M. E. \& Hammad, M. M. Maximum occlusal bite forces in Jordanian individuals with different dentofacial vertical skeletal patterns. Eur. J. Orthod., 32(1):71-7, 2010.

Alvaran, N.; Roldan, S. I. \& Buschang, P. H. Maxillary and mandibular arch widths of Colombians. Am. J. Orthod. Dentofacial Orthop., 135(5):649-56, 2009.

Aragón, N.; Bastidas, C.; Bedón, L.; Duque, P.; Sánchez, M.; Rivera, S.; Triana, F.; Bedoya, A. \& Moreno, F. Rasgos morfológicos dentales coronales en dentición temporal y permanente: Distancia biológica entre tres grupos indígenas del Amazonas Colombiano. Rev. Odontol. Mex., 12(1):13-28, 2008.

Bedoya, A.; Rivera, S. \& Triana, F. Occlusion analysis of a native school children population in Amazonas. Int. J. Jaw Func. Orthop., 1:525-42, 2005.
Bedoya, A.; Osorio, J. \& Tamayo, J. A. Facial Biotype in Three Colombian Ethnic Groups: a New Classification by Facial Index. Int. J. Morphol., 30(2):677-82, 2012.

Bedoya, A.; Osorio J. C. \& Tamayo, J. A. Determinación del biotipo facial basado en características fenotípicas a través del modelo de ecuaciones estructurales: estudio sobre tres etnias. Rev. Fac. Odontol. Univ. Antioq., 25(1):132-46, 2013.

Clark, W. J. Twin Block Functional Therapy. Applications in Dentofacial Orthopaedics. 2nd ed. London, Mosby-Wolfe, 2002.

Evensen, J. P. \& Ogaard, B. Are malocclusions more prevalent and severe now? A comparative study of medieval skulls from Norway. Am. J. Orthod. Dentofacial Orthop., 131(6):710-6, 2007.

Forster, C. M.; Sunga, E. \& Chung, C. H. Relationship between 
dental arch width and vertical facial morphology in untreated adults. Eur. J. Orthod., 30(3):288-94, 2008.

Gavião, M. B.; Raymundo, V. G. \& Rentes, A. M. Masticatory performance and bite force in children with primary dentition. Braz. Oral Res., 21(2):146-52, 2007.

Kamegai, T.; Tatsuki, T.; Nagano, H.; Mitsuhashi, H.; Kumeta, J.; Tatsuki, Y.; Kamegai, T. \& Inaba, D. A determination of bite force in northern Japanese children. Eur. J. Orthod., 27(1):537, 2005.

Keski-Nisula, K.; Lehto, R.; Lusa, V.; Keski-Nisula, L. \& Varrela, J. Occurrence of malocclusion and need of orthodontic treatment in early mixed dentition. Am. J. Orthod. Dentofacial Orthop., 124(6):631-8, 2003.

Kiliaridis, S.; Engström, C. \& Thilander, B. The relationship between masticatory function and craniofacial morphology. I. A cephalometric longitudinal analysis in the growing rat fed a soft diet. Eur. J. Orthod., 7(4):273-83, 1985.

Lindsten, R.; Ogaard, B.; Larsson, E. \& Bjerklin, K. Transverse dental and dental arch depth dimensions in the mixed dentition in a skeletal sample from the 14th to the 19th century and Norwegian children and Norwegian Sami children of today. Angle Orthod., 72(5):439-48, 2002.

Lu, X.; Chen, H. \& Jain, A. K. Multimodal Facial Gender and Ethnicity Identification. In: Zhang, D. \& Jain, A. (Eds.). Advances in Biometrics. Heidelberg, Springer, 2005. pp.55461.

Mao, J. J. \& Nah, H. D. Growth and development: hereditary and mechanical modulations. Am. J. Orthod. Dentofacial Orthop., 125(6):676-89, 2004.

Nakatsuka, M.; Iwai, Y.; Jue, S. S.; Oh, S. H.; Guo, L.; Tominaga, Y. \& Kumabe, S. A morphological study on the classification of maxillary dental arches. Okajimas Folia Anat. Jpn., 81(1):5$13,2004$.

Padilla, M.; Tello, L.; Moreno, F.; Osorio, J. C. \& Bedoya, A. Analysis of Dental Arch Dimensions in Three Colombian Ethnic Groups. Int. J. Morphol., 31(1):100-6, 2013.

Rakosi, T. \& Irmtrud, J. Atlas de Ortopedia Maxilar: Diagnóstico. Barcelona, Salvat, 1992.

Regalo, S. C.; Santos, C. M.; Vitti, M.; Regalo, C. A.; de Vasconcelos, P. B.; Mestriner, W. Jr.; Semprini, M.; Dias, F. J.; Hallak, J. E. \& Siéssere, S. Evaluation of molar and incisor bite force in indigenous compared with white population in Brazil. Arch. Oral Biol., 53(3):282-6, 2008.

Ricketts, R. M. A foundation for cephalometric communication. Am. J. Orthod., 46:330-57, 1960.
Ross-Powell, R. E. \& Harris, E. F. Growth of the anterior dental arch in black American children: a longitudinal study from 3 to 18 years of age. Am. J. Orthod. Dentofacial Orthop., 118(6):649-57, 2000.

Shinogaya, T.; Bakke, M.; Thomsen, C. E.; Vilmann, A.; Sodeyama, A. \& Matsumoto, M. Effects of ethnicity, gender and age on clenching force and load distribution. Clin. Oral Investig., 5(1):63-8, 2001.

Sondang, P.; Kumagai, H.; Tanaka, E.; Ozaki, H.; Nikawa, H.; Tanne, K. \& Hamada, T. Correlation between maximum bite force and craniofacial morphology of young adults in Indonesia. J. Oral Rehabil., 30(11):1109-17, 2003.

Sonnesen, L. \& Bakke, M. Molar bite force in relation to occlusion, craniofacial dimensions, and head posture in pre-orthodontic children. Eur. J. Orthod., 27(1):58-63, 2005.

Varga, S.; Spalj, S.; Lapter Varga, M.; Anic Milosevic, S.; Mestrovic, S. \& Slaj, M. Maximum voluntary molar bite force in subjects with normal occlusion. Eur. J. Orthod., 33(4):427-33, 2011.

\section{Correspondence to:}

Antonio Bedoya Raodríguez

Posgrado de Ortodoncia y Ortopedia Maxilar

Institución Universitaria Colegios de Colombia (UNICOC)

Cali

COLOMBIA

Email: nbedoya@unicoc.edu.co

Received: 10-07-2014

Accepted: $30-12-2014$ 